\title{
Law-Related Education Framework in Civic Education Learning in the New Normal Perspective
}

\author{
Baeihaqi Baeihaqi ${ }^{1,{ }^{*}}$ Kokom Komalasari $^{2}$ \\ ${ }^{1,2}$ Universitas Pendidikan Indonesia, Bandung, Indonesia \\ *Corresponding author.Email: baeihaqi@upi.edu
}

\begin{abstract}
The COVID-19 pandemic has implications for the provision of education through online distance learning or blended learning. The implementation of education through balanced learning is carried out by limiting the number of students, checking temperature, washing hands with soap and running water, using masks and disinfectants regularly and maintaining distance during the learning process, while in the context of online learning, it is done virtual learning schemes. Law-related education (LRE) in civic education basically plays a role in teaching law to citizens so that people have legal awareness. Through this LRE, citizens have the will of the law, so they are able to control and filter out acts that violate the law, and have the ability to obtain legal protection. This also has implications for fulfilling the role of citizens in carrying out their rights and obligations as part of society in exercising social control. Substantially, the elements of LRE and civic education are correlated with development literacy and legal awareness of citizens. These elements include subject matter, practice and instructional context, skills, and attitudes, beliefs, and values. The elements are the main aspects that are in line with the three main elements of civic education which include the development of affection, cognition, and psychomotor. The LRE framework in Civic Education is comprehensively integrated in the learning component of Civic Education. These components are integrated in the development of LRE which is based on the context of a reconstructive educational philosophy that places Pancasila as a central value.
\end{abstract}

Keywords: Civic education, distance learning, law-related education, new normal.

\section{INTRODUCTION}

The COVID-19 pandemic, which is still ongoing now, has forced people to make changes to their lifestyle with new orders and adaptations of habits (new normal) in order to live productively and avoid the transmission of COVID-19. The risk of people's movement and community gathering has a fairly large potential for COVID-19 transmission. The implication is that the implementation of education must be carried out by distance learning through online learning or blended learning. This is done as an effort to prevent the spread of COVID-19 by applying discipline in the application of the principles of a cleaner and healthier lifestyle as the key in suppressing the transmission of COVID-19 in the community in clusters of viruses spread in educational institutions. In this context, it is an effort to prevent the transmission of new cases in adapting new habits by implementing strict health protocols in every learning activity. Based on this, the LRE learning process in civic education is also carried out by distance learning. LRE is oriented towards developing legal awareness of the citizens which is applied in Civic education learning as a forum and means of LRE in Indonesia.
Legal awareness is the basic foundation of public compliance, responsibility, participation, and obedience to the law, both written and unwritten. This is because the law cannot be separated from human life, where the law is made to control human association. Cicero said that where there is society there is a law (ubi societas ibi ius) [1], so legal awareness is important for every individual. When the community has awareness of the law, the community has an insight into knowledge and understanding related to the law which is applied to legal attitudes and behavior in carrying out their role in the life of society, nation, and state.

This awareness orientation shows that the strength and existence of sanctions for violations and legal crimes certainly cannot guarantee that the community will obey and obey the law, except in certain objective conditions so that a legal event occurs and results in law enforcement efforts within the scope of legal system for the purpose of fulfilling a sense of justice. This is because the level of one's consciousness depends on the basis of the foundation of the formation of consciousness itself. This is because the level of one's consciousness depends on the basis of the foundation of the formation of 
consciousness itself. In this context, legal awareness is an important aspect that must be owned by every community as an element of the citizenship aspect so that each individual community has the highest level of awareness in carrying out its functions and roles. The solution so that legal awareness is felt by every individual in society can be done through LRE.

Citizens within legal limits are beings who have the right to obtain state protection and act according to the applicable legal rules and refer to political agents as attached to the status of citizens [2]. The implication of citizenship status forms the rights and obligations of citizens towards their country as legitimized in the state constitution which is a form of general agreement between the authorities and their people in the administration of the state. The legal relationship between individuals and the government itself is described in the concept of citizenship in which the individual is understood as an autonomous and sovereign subject, and the government is understood as a nationstate [3];[4]. The context of the relationship is basically formed based on the agreement on the formation of a legitimate state in the state constitution as the legal basis for state administration as a fundamental norm.

LRE is a solution in building legal awareness, because through LRE the community will be taught about knowledge related to law and how to understand the law, how to respond to the law, and arrive at the level of application of legal behavior. LRE in schools in Indonesia is basically integrated into the subjects of Civic Education. Civic education as LRE is based on the scope of Civic education as an educational program with a core of political democracy and is an extension of the science of Civics [5]. This is because the scope of political democracy and citizenship is basically structured, one of which is the substance of the application of law in the life of the nation and state.

This LRE will certainly encourage the level of legal literacy of the community and will have an impact on the participation and active involvement of the community in carrying out their functions and roles as citizens. Aspects that encourage active community participation and involvement are basically in knowledge and insight into the law, knowing and having this knowledge makes people understand their functions and roles in democratic state administration and how to carry out their rights and obligations as citizens attached to their citizenship status. Without legal knowledge, society and the younger generation will not be able to function effectively within the boundaries of democracy [6].

The statement identifies that democracy will not work effectively without the legal awareness of the people in which knowledge of the law is an important basis for the fulfillment and protection of human rights as a form of their rights and obligations as citizens in accordance with the agreement to form a state, and the theory of popular sovereignty is the basis of the theory. democratic countries as a general agreement state formation. The people have the highest sovereignty in the administration of the state and the government as the people's mandate is given the power to administer the state. Therefore, legal education and civic education have an important role in building legal awareness of citizens so that they can carry out their roles and functions in the life of society, nation, and state.

\section{FREAMWORK OF LAW-RELATED EDUCATION AND CIVIC EDUCATION}

The term LRE has basically existed more than about thirty years ago to describe the type of legal education that is appropriate for students in schools to learn and distinguish it from the type of legal education for legal experts/lawyers [7]. This is because legal education for legal experts or lawyers requires knowledge of facts and details about various fields of law, while students in schools need to learn about the law and its role in social life.

LRE was basically developed as a response to the failure of traditional civic education to influence the level of legal and political awareness [8]. Therefore, LRE is defined as education to equip law-native people with knowledge and skills related to law, the legal process, and the legal system, with a commitment to the democratic principles and values on which these principles are based [6]; [9], so that LRE can be understood as education to cultivate the knowledge, skills, and values needed by citizens to function effectively in a pluralistic and democratic society based on the rule of law [9].

The implication is that LRE has a role to play in helping communities develop an understanding of the legal and judicial system, as well as to provide them with functional knowledge about the operation of legal institutions [10]. This is because LRE is concerned with the concepts of law, justice, freedom, and equality which emphasizes the relationship between citizens and society, as well as their role in a legal process [11]. In this context, basically, LRE seeks to formulate and reorganize the basic concepts of law and the legal system for pedagogical purposes to increase knowledge and application of the law by the public [10];[12].

This explanation shows that the LRE program is oriented towards equipping young citizens with legal knowledge and skills so that they can carry out their functions and roles in society and become provisions for later adulthood in democratic life in accordance with the rule of law. This orientation indicates the purpose of legal learning is to teach the community about the law so that they have legal awareness which is basically part of the purpose of civic education, therefore legal education should be taught from an early age for the younger generation which must be carried out continuously and adapted to the pedagogical development of children. This is because Civics basically acts as a vehicle for legal education outside of learning at the law faculty, both from basic education, secondary education, and higher education. 
The role of Civics in developing legal awareness is correlated with the development of knowledge, understanding, attitudes, and legal behavior of citizens so that they are able to equip them as citizens who can carry out the rights and obligations inherent in their citizenship status. both in the life of society, nation, and state. Civics as legal education in developing legal awareness in several countries basically refers to legal education, street law education, and not civic education [13]. The difference is because in each country legal education is carried out differently, but in Indonesia legal education outside the law, faculty is integrated into Civics. Through law-related education, will certainly encourage the level of legal literacy and awareness of the community, and will have an impact on the participation and active involvement of the community in carrying out their functions and roles as citizens. This is because one of the goals of LRE is to develop legal literacy [14];[15];[16].

The function of LRE in Civic education is basically directed to the ability to maintain values that are considered good by the community, because the function of law itself is to maintain public order. In this context, of course, the basic values that make up the law must be based on religious values and the socio-cultural values of the community, so that they can represent rules or regulations that are in accordance with the socio-cultural conditions of the community. This is in line with the statement of Rahardjo that the presence of the law is to uphold the values of society and is considered as the embodiment of the content of these values [17].

The construction of the LRE framework in civic education is substantially integrated with reference to the synchronized LRE elements in the Civics learning components. Substantially, the elements of LRE and civic education are correlated with developing literacy and legal awareness of citizens. These elements include subject matter, practice and instructional context, skills, and attitudes, beliefs, and values. The elements are the main aspects that are in line with the three main elements of civic education which include the development of affection, cognition, and psychomotor.

LRE in civic education basically plays a role in teaching law to citizens so that people have legal awareness. Through this LRE, citizens have the will of the law, so they are able to control and filter out acts that violate the law, and have the ability to obtain legal protection. This also has implications for fulfilling the role of citizens in carrying out their rights and obligations as part of society in exercising social control. Substantially, the elements of LRE and civic education are correlated with the development of legal literacy and legal awareness of citizens.

Based on this, LRE is an approach that is in accordance with the mission of Civics as legal education. This shows that Civic education as a vehicle for LRE has urgency in people's social life because LRE in Civic education plays a role in the process of internalizing law for the citizens. In this context, LRE is also a solution in the form of repressive measures to protect the younger generation from committing acts that violate the law, both violations, and crimes. At the same time, Civic education as LRE encourages an important role in preparing generations to take an active part in the administration of the state, so that the administration of government can be carried out democratically. This is because civic education/citizenship education is strategically positioned as one of the basic requirements for the implementation of a democratic government under the rule of law.

The position of Civic education as LRE is stated in the International Commission of Jurist, which at the conference of international organizations of legal experts held in Bangkok in 1965 described the conditions for the democratic government under the rule of law, namely: "(1). Constitutional protection, in the sense, that the constitution in addition to guaranteeing individual rights, must also determine the procedural way to obtain the protection of guaranteed rights; (2) independent and impartial tribunals; (3). Free elections; (4) Freedom of expression; (5). Freedom of association for association/organization and opposition; and (6). Civic Education/Citizenship Education" [18]. This is in line that LRE is also intended as part of education for citizens. Education for citizens is expressed in three phrases, namely: "civic education" "citizenship education" or "public education" [14]. In the context of the position of Civic education as LRE, it means that Civic education is LRE in a constitutional democracy or a democracy based on law.

The role of LRE in developing citizenship includes: First, being interested in legal issues that are currently happening in society. Second, discuss cooperatively with various people to solve legal problems. Third, utilizing views and thoughts on legal matters [15];[16]. This is certainly in line with the mandate of Article 1 Paragraph 2 of the 1945 Constitution of the Republic of Indonesia which contains the principle of a democratic state, namely sovereignty is in the hands of the people, and Article 1 or 3 of the 1945 Constitution of the Republic of Indonesia which expressly states that Indonesia is a state of law.

LRE is about developing a more critical and socially responsible awareness of citizenship, and about giving students the skills to make a positive difference in society and the nation [7];[19]. This goal is an integral part of the expectations of educational social studies; namely, preparing our youth for citizenship, developing students' abilities to think critically about an issue, and encouraging students to take action to make the world a better place [17].

Based on this explanation, education that is oriented to the legal internalization process is a must. The realization of this is through Civic education which acts as a vehicle for LRE for the citizens. Even within the scope of social life, knowledge, and understanding of the law are very much needed in regulating public order. The 
integral of knowledge and understanding of the law will be realized in the form of attitudes and behavior that do not conflict with the law. This combination of knowledge, understanding, attitude, and legal behavior is called legal awareness.

The purpose of LRE is not only to prepare people who are proficient in law but also to help the community implement a law-abiding culture. This is because in the reality of social, national, and state life, everyone is required to have an awareness of the law. For example, knowing and being aware of positive law, and with awareness related to legal knowledge, the community can carry out its role as social control in the administration of the state which has implications for the enforcement of justice that can be developed effectively. This is because "law is something that can make a person aware of goodness and justice. The failure to enforce various existing laws is also an indication of the low level of public understanding of these laws" [20].

To support and encourage the enforcement of the law, of course, LRE is needed in building legal awareness. Through the success of building this awareness, it will assist in monitoring and evaluating the implementation of the law so that irregularities and violations of the law can be reduced. Because through knowledge and insight into the law, people will understand their functions and roles in democratic state administration and can encourage active citizen participation and involvement (civic participation).

\section{PRACTICE OF LAW-RELATED EDUCATION LEARNING IN CIVIC EDUCATION IN NEW NORMAL ERA}

The construction of the scenario for the implementation of distance education is carried out using an online learning scheme or blended learning. The implementation of education through blended learning is carried out by limiting the number of students, checking temperature, washing hands with soap and running water, using masks and disinfectants regularly, and maintaining distance during the learning process, while in the context of online learning it is carried out using a virtual learning scheme. The distance learning application is carried out synchronously and asynchronously.

The implementastion of blended learning is applied in adapting new habits by implementing health protocols in every activity to lead to preparation for a new normal, productive, and safe by adopting the adaptation of these new habits. The adaptations of the new habits in question are: frequently washing hands with soap, wearing masks, maintaining a minimum distance of 1 meter, getting enough rest, exercising diligently, managing stress, and consuming balanced nutritious foods [21].

In the implementation of distance learning, learning media must be used optimally so that it not only functions as a learning aid but also as a learning resource.
This must also be supported by placing the teacher as the main learning component in the teaching and learning process. This is because of the implementation of lawrelated education in Civics learning in the new normal era in distance learning in media learning patterns. Through this pattern, the teacher is not the only source of learning, so that learning activities lead to the development of a student center.

The application of the media learning pattern in LRE learning in PKN can be carried out using inquiry learning methods, experience-based learning, and problem-based learning [15];[16];[22]. LRE also includes many educational strategies and teaching methods such as simulation, moot court, mock trial, and others. These strategies and methods are applied as a way to operationalize learning activities so that learning materials can be reached properly.

These various educational methods aim to foster children's abilities such as the ability to choose, the ability to argue, and the ability to think, and the ability to express [15];[16]. LRE programs in schools, usually implemented with support from local bar associations, involve volunteer law enforcement officers and lawyers who serve as community resource persons in social science classrooms. Volunteers and teachers educate students about the law through a combination of standard pedagogy and interactive activities, such as mock trials, mock trials, or debates [11];[23];[24]. This shows that LRE helps students gain broader benefits related to understanding why we have laws, legal sources, legal institutions and structures, and other aspects of the legal basis [7].

LRE program that has a significant impact, basically by involving resource persons from the community relevant to the subject being studied and integrating it into teaching and learning activities in class with the same group of students over a period of time [25]. This is because LRE provides students with an active learning experience that allows them to explore rights and responsibilities according to the rule of law, face and resolve disputes, and be able to analyze and analyze public issues [9].

Thus, LRE basically encourages the development of long-life skills needed by all citizens, including critical thinking skills; decision making, problem-solving, communication, cooperation, reasoning, use, citizen participation, and acting appropriately on information; and participate effectively in law-based societies [9];[25]. The development of these skills, especially for children in LRE, becomes a standard reference in the LRE learning process to be applied and transmitted into learning instructional objectives and must be adapted to the content and subject of LRE. Isoyama [15];[16] revealed that the scope of the LRE program includes:

1. The legal principles and values that these principles are

2. Bill of Rights and other constitutional laws

3. The role and limits of law in a democratic society 
4. Conflict and problem solving

5. The role of law in avoiding conflict and resistance

6. Development and administration rules

7. Administration of the criminal and civil justice systems, and their strengths and weaknesses

8. Informal law

9. Authority, freedom, enforcement, and punishment

10. Law as a vehicle for resolving and resolving social and political problems

11. Legal fields that affect the daily life of citizens

12. International Relations, Anthropology, and Economics.

The context of the LRE illustrates that the legal context is not limited to narrow rules for substantive rules, found in laws or legal cases but rather includes broader content such as the principle of balance, balance, the law of process, custom, and practice. and the day-today impact of laws and the legal system. Contents of LRE Reflect the ideas or concepts that underlie the understanding of the legal system such as rights, responsibilities, authority, justice, and shared responsibilities. LRE also examines the file values or beliefs contained in our laws, such as against property and human life [7].

Based on the explanation above, LRE in Civic education must be carried out in an integrative and collaborative manner in a comprehensive learning process scheme. Somantri argues that "in developing and implementing Civic education it must be patterned on an integrative line of thinking, namely a unified whole of the relationship between intraceptive knowledge (religion, values) and extraceptive knowledge (science), Indonesian culture, national education goals, Pancasila, the 1945 Constitution of the Republic of Indonesia, educational philosophy, educational psychology, curriculum development for social sciences and humanities disciplines, then an educational program is made which consists of the following elements: (1) educational objectives, (2) educational materials, (3) educational methods, (4) evaluation" [5].

Thus, the implementation of legal learning in PPKn must be carried out in an integrative and collaborative manner in its application both in materials, methods, media, learning resources and learning evaluation by emphasizing the development of good learning habits for students with orientation to the development of independent learning. The reference for the implementation must be oriented to media learning patterns and teacher and media learning patterns, so that it can be an effort to minimize the limitations of Civic education learning in the new adaptation period, but still be oriented to the development of active participation of students in the teaching and learning process.

\section{CONCLUSION}

The LRE framework in Civic Education is basically comprehensively integrated into the learning components of Civic Education. These components are integrated into the development of LRE which is based on the context of a reconstructive education philosophy that places Pancasila as a central value. The LRE element in civic education is correlated with developing literacy and legal awareness of citizens. These elements include subject matter, practice and instructional context, skills, and attitudes, beliefs, and values. These elements are the main aspects that are in line with the three main elements of civic education which include the development of affection, cognition, and psychomotor. The role of LRE in civic education aims to teach law to citizens so that people have legal awareness. Through the LRE, citizens have the will of the law, so they are able to control and filter out acts that violate the law, and have the ability to obtain legal protection. This also has implications for fulfilling the role of citizens in carrying out their rights and obligations as part of society in exercising social control.

\section{REFERENCES}

[1]. Prasetyo, T. (2013). Hukum dan Sistem Hukum Berdasarkan Pancasila. Yogyakarta: Media Perkasa

[2]. Kalidjernih, F. K. (2011). Pusparagam konsep dan isu kewarganegaraan. Bandung: Widya Aksara.

[3]. Block, D. (2011). Citizenship, education and global spaces. Language and Intercultural Communication, 11(2),161-169.

https://doi.org/10.1080/14708477.2011.556743

[4]. Sassen, S. (2006). Territory, authority, rights : from medieval to global assemblages, vol. 53. Princeton, New Jersey: Princeton University Press. https://doi.org/10.1017/CBO9781107415324.004

[5]. Somantri, M.N. (2001). Menggagas Pembaharuan Pendidikan IPS. Bandung: PT Remaja Rosdakarya.

[6]. Dejong, L.E. (2016). Law Related Education: The Growth Law-Related Education. Newslatter of Illinois State Bar Association. 1, (3), 4

[7]. Cassidy, W. (2004). Don't Forget About Law: A Case For LawRelated Education In Elementary Social Studies. Canadian Social Studies, 39 (1).

[8]. Rowe, D. Law-related Education: An Overview in Lynch, J. Modgil, C. and modgil, S. (2013). Cultural diversity and the schools: Vol. 4. Human rights, education and global responsibilities. New York: Routledge Taylor \& Francis Group.

[9]. American Bar Association, Special Committee on Youth Education for Citizenship (2003). Essentials of Law-Related Education. Chicago, IL: American Bar Association. 
[10]. Ikwumelu, S.N. (2013). Social studies education in Nigeria: An overview. Onitsha: Outrite publishers.

[11]. Marri, A. R. (2010). Using Law-Related Education to Engage Marginalized Urban High School Students. Action in Teacher Education, 32:3, 40-54, DOI:10.1080/01626620.2010.10463558

[12]. Ikwumelu, S. N., P. E. Eluu, and O. A. Oyibe. (2014). Law- related education : a catalyst for crime prevention and control in nigeria, African Educ. Indices, vol. 7, no. 1, pp. 1-8.

[13]. Sapriya. (2007). Peran Pendidikan Kewarganegaraan dalam Membangun Karakter Warga Negara. Jurnal Sekolah Dasar, 16, No. 1, pp 22-34 [online]. Tersedia: http://jurnal.pdii.lipi.go.id/admin/jurnal/161072234. pdf

[14]. Isoyama, K. (2018a). Practice Of Law-Related Education to Develop Legal Literacy. Resource Material Series, no. 105, pp. 127-134.

[15]. Isoyama, K. (2018a). Practice Of Law-Related Education To Develop Legal Literacy. Resource Material Series, no. 105, pp. 127-134.

[16]. Isoyama, K. (2019). Law related education in japan - developments and challenges. Int. J. Publik Educ., vol. 3 , no. 68 , pp. 1-17.

[17]. Maftuh, B. \& Sapriya. (2005). Pembelajaran PKn melalui Konsep. Jurnal Civicus, 1, (5), 319-328
[18]. Budiardjo, M. (2008). Dasar-dasar Ilmu Politik. Jakarta: PT. Gramedia Pustaka Utama.

[19]. Cassidy. A. 2000. A practical Guide to Information System Strategic Planning, Second Edition.

[20]. Isep. 2013 Peranan Pendidikan Kewarganegaraan sebagai Pendidikan Hukum dalam Mengupayakan Internalisasi Hukum di Kalangan Peserta Didik. Jurnal Penelitian Pendidikan, 13 (1). DOI: https://doi.org/10.17509/jpp.v13i1.3474

[21]. Kementerian Kesehatan RI. (2020). Protokol Dukungan Kesehatan Jiwa dan Psikosial (DKJPS) Anak dan Remaja pada Masa Adaptasi Kebiasaan Baru Pandemi COVID 19. Jakarta: Kementerian Kesehatan RI

[22]. Study Group on Law-Related Education. (1978). Final report of the U.S. Office of Education Study Group on Luw-Related Education. Washington, DC: US. Government Printing Office.

[23]. Hess, D. (1997). Violence prevention and service learning. Social Education, 61(5), 279-281.

[24]. Hanson, R. (2002). The case for law-related education. Educational Leadership, 59(4), 61-64.

[25]. Street Law. (2006). Best practices in law-related education (LRE). Silver Spring, MD: Author. 